\title{
ASSOCIATIONS BETWEEN GLUTAMATE CYSTEINE LIGASE CATALYTIC SUBUNIT GENE POLYMORPHISMS AND CLINICAL CHARACTERISTICS OF ISCHEMIC STROKE
}

Bocharova $Y A^{1,2} \otimes$

${ }^{1}$ Belgorod State National Research University, Belgorod, Russia

2 Kursk Regional Clinical Hospital, Kursk, Russia

An imbalance between the production of reactive oxygen species and their neutralization lies at the core of oxidative stress implicated in ischemic stroke (IS) and the subsequent brain tissue damage. The aim of this study was to investigate the effects of common polymorphic variants of the glutamate cysteine ligase catalytic subunit gene on the extent of brain damage and clinical manifestations in patients with ischemic stroke. A total of 589 ischemic stroke survivors were genotyped for 6 single nucleotide polymorphisms (SNPs) of the GCLC gene, including rs12524494, rs17883901, rs606548, rs636933, rs648595 and rs761142, using a MassARRAY-4 analyzer. The study found that genotypes rs636933-G/A-A/A ( $p=0.009)$ and rs761142-A/C-C/C $(p=0.015)$ were associated with an enlargement of the cerebral lesion size. Genotypes rs12524494-G/G $(p=0.05)$ and rs606548-T/T $(p=0.003)$ were associated with a risk of 2 or more IS episodes. Genotype rs17883901-G/A was associated with early onset of IS $(p=0.004)$. The study revealed multiple associations of GCLC SNPS with the clinical manifestations of ischemic stroke. Thus, GCLC polymorphisms are important DNA markers affecting the size of the cerebral lesion in patients with ischemic stroke and are associated with age at onset, the number of past strokes and the clinical manifestations of the disease.

Keywords: ischemic stroke, cerebral infarction, redox homeostasis, glutathione, glutamate cysteine ligase, single nucleotide polymorphism

Acknowledgements: the author thanks Polonikov AV, Azarova YuE, Klyosova EYu, Bykanova MA and Bushueva OYu of the Research Institute of Genetic and Molecular Epidemiology (Kursk State Medical University) for their help in conducting molecular genetic studies.

Compliance with ethical standards: the study was approved by the Ethics Committee of Kursk State Medical University (Protocol № 5 dated June 25, 2012); all study participants gave voluntary informed consent to participate.

$\triangle$ Correspondence should be addressed: Yulia A. Bocharova

Sumskaya, 45a, Kursk, 305007; y_u_I_i_a_03@mail.ru

Received: 21.01.2021 Accepted: 06.02.2021 Published online: 23.02.2021

DOI: $10.24075 /$ brsmu.2021.007

\section{АССОЦИАЦИЯ ПОЛИМОРФНЫХ ВАРИАНТОВ ГЕНА КАТАЛИТИЧЕСКОЙ СУБЪЕДИНИЦЫ ГЛУТАМАТЦИСТЕИНЛИГАЗЫ С КЛИНИЧЕСКИМИ ХАРАКТЕРИСТИКАМИ ИШЕМИЧЕСКОГО ИНСУЛЬТА}

Ю. А. Бочарова ${ }^{1,2} \bowtie$

${ }^{1}$ Белгородский государственный национальный исследовательский университет, Белгород, Россия

2 Курская областная клиническая больница, Курск, Россия

\begin{abstract}
Дисбаланс между образованием активных форм кислорода и их обезвреживанием лежит в основе окислительного стресса - патологического процесса, патогенетически связанного с развитием ишемического инсульта (ИИ) и последующими этапами постишемического повреждения тканей головного мозга. Целью настоящего исследования было изучение влияния частых полиморфных вариантов гена GCLC каталитической субъединицы глутаматцистеинлигазы на степень поражения головного мозга и клинические проявления у больных с ишемическим инсультом. У 589 пациентов с ишемическим инсультом было проведено генотипирование шести однонуклеотидных полиморфизмов (SNP) rs12524494, rs17883901, rs606548, rs636933, rs648595 и rs761142 гена GCLC с помощью генетического анализатора MassARRAY-4. Установлено, что генотипы rs636933-G/A-A/A ( $p=0,009)$ и rs761142-A/C-C/C ( $p=0,015)$ ассоциированы с увеличением зоны инфаркта мозга. Генотипы rs12524494-G/G (p = 0,05) и rs606548-T/T $(p=0,003)$ ассоциировались с возникновением двух и более эпизодов ИИ. Генотип rs17883901-G/A был ассоциирован с более ранним дебютом ИИ ( гена GCLC являются значимыми ДНК-маркерами, влияющими на зону инфаркта мозга у больных ишемическим инсультом, ассоциированы с возрастом дебюта первого инсульта, числом перенесенных инсультов и клиническими проявлениями болезни.
\end{abstract}

Ключевые слова: ишемический инсульт, инфаркт мозга, редокс-гомеостаз, глутатион, глутаматцистеинлигаза, однонуклеотидный полиморфизм

Благодарности: автор выражает благодарность сотрудникам научно-исследовательского института генетической и молекулярной эпидемиологии Курского государственного медицинского университета А. В. Полоникову, Ю. Э. Азаровой, Е. Ю. Клёсовой, М. А. Быкановой и О. Ю. Бушуевой за помощь в выполнении молекулярно-генетических исследований.

Соблюдение этических стандартов: исследование одобрено этическим комитетом Курского государственного медицинского университета (протокол № 5 от 25 июня 2012 г.); все участники подписали добровольное информированное согласие на участие в исследовании.

$\bigotimes$ Для корреспонденции: Юлия Александровна Бочарова ул. Сумская, д. 45а, г. Курск, 305007; у_u__i_a_03@mail.ru

Статья получена: 21.01.2021 Статья принята к печати: 06.02.2021 Опубликована онлайн: 23.02.2021

DOI: $10.24075 /$ vrgmu.2021.007

Cerebrovascular disease or, more specifically, ischemic stroke (IS) is among the leading causes of death and disability in highincome countries [1]. The etiology of IS is multifactorial, i.e. the disease is driven by the complex interplay of genetic and environmental factors [2]. Multiple studies have demonstrated that redox homeostasis disturbances manifesting as an imbalance between the production of reactive oxygen species and their neutralization lie at the core of oxidative stress implicated in IS and the subsequent brain tissue damage [3]. It is a well-known fact that oxidative stress plays a significant role in the pathogenesis of IS, especially in the acute stroke phase [4, 5]. Glutathione is a powerful body antioxidant; disorders of glutathione metabolism often result in disrupted redox homeostasis and oxidative stress, possibly contributing to postischemic brain damage [6, 7]. In patients predisposed to IS, glutathione deficiency might be associated with genetic variation that affects the activity of enzymes involved in glutathione synthesis $[8,9]$. Glutamate cysteine ligase is the key 
enzyme that catalyzes the first step of glutathione synthesis. It is composed of a catalytic and a modifier subunits encoded by several genes. Their polymorphic variants determine the variability in glutamate cysteine ligase activity and glutathione levels. However, so far no research studies have explored the effects of polymorphisms in glutathione metabolism genes on the extent of ischemic brain damage and the clinical manifestations of stroke. The aim of this study was to investigate the effects of common polymorphic variants of the glutamate cysteine ligase catalytic subunit gene on the extent of brain damage and the clinical manifestations of stroke in patients with IS.

\section{METHODS}

The study was carried out in 589 ischemic stroke survivors (330 men and 270 women; mean age 61.1-9.8 years) admitted to Kursk Regional Clinical Hospital between 2007 and 2017 The following inclusion criteria were applied: IS confirmed by clinical examination and imaging tests; Caucasian origin; voluntary informed consent to participate. Patients of nonCaucasian origin, with hemorrhagic stroke or those who did not give voluntary consent to participate were excluded from the study. Of all patients included in the study, $75 \%$ were Russian, i.e. at least 2 previous generations of the probands were Russian. IS was confirmed by qualified neurologists of Kursk Regional Clinical Hospital; the diagnosis was based on the neurological examination and imaging tests, including brain CT and MRI scans.

The patients were genotyped for 6 GCLC polymorphisms: rs12524494, rs17883901, rs606548, rs636933, rs648595, and rs761142. Candidate SNPs available in the HapMap catalogue were selected using the GenePipe tool [10]. Only those tagSNPs were selected that had at least 5\% minor allele frequency and were in linkage disequilibrium with 2 or more SNPs. The functional significance of SNPs was assessed using the FuncPred software (SNPinfo Web Server) [11].

DNA was isolated from the frozen venous blood samples of the participants according to the standard protocol of phenolchloroform extraction and ethanol precipitation. Moleculargenetic procedures, including SNP genotyping, were carried out at the Research Institute for Genetic and Molecular Epidemiology of Kursk State Medical University in 2016-2017. SNPs genotyping was performed using the iPLEX technology and a MALDI-TOF MassARRAY 4 analyzer (Agena Bioscience; USA).

The associations between the studied SNPs and the clinical manifestations of IS were analyzed by calculating the odds ratio and $95 \% \mathrm{Cl}$ using logistic regression with adjustments for age and sex; the statistical analysis was carried out in SNPStats (Catalan Institute of Oncology; Spain). Effects of the studied SNPs on the size of cerebral lesions measured by $\mathrm{MRI}$ and expressed in millimeters, on age at stroke onset and the number of previous cerebrovascular episodes were analyzed in SNPStats. The functional annotation of GCLC polymorphisms and the assessment of their regulatory potentia from tissue-specific expression were performed using a battery of bioinformatic tools, including GTEx portal [12] and eQTLGen [13]. These databases host genomic and transcriptomic data that can be used to assess the effects of the analyzed SNPs on the levels of GCLC expression in the brain, arteries and blood.

\section{RESULTS}

The analysis of genotype frequencies revealed that only one GCLC polymorphism (rs648595) significantly deviated from the Hardy-Weinberg equilibrium due to a decrease in heterozygosity
( $0<0.05)$. In patients with IS, genotype frequencies of the studied GCLC polymorphisms were as follows (the numbers represent genotypes homozygous for the reference allele, heterozygous, and homozygous for the minor allele, respectively): 93.5, 5.8, 0.7 (rs12524494); 85.4, 13.7, 1.0 (rs17883901); 93.7, 6.0, 0.3 (rs606548); 63.5, 31.6, 4.8 (rs636933); 16.3, 52.1, 31.6 (rs648595); 57.2, 37.8, 4.9 (rs761142). Clinically, it was interesting to explore the potential involvement of the studied polymorphisms in cerebral infarction growth, necrotic cell death and inflammation due to cerebral artery occlusion, and in some processes related to postischemic repair of damaged tissue. Using linear regression, we analyzed associations between the studied GCLC polymorphisms and the size of cerebral lesions $(\mathrm{S}, \mathrm{mm})$ in patients with IS. We found that polymorphisms rs636933 and rs761142 were significantly associated with the size of the cerebral lesion in patients with ischemic stroke regardless of their age or sex. Specifically, genotypes G/AAVA of the rs636933 polymorphism (the dominance effect of SNP) were associated with a statistically significant (by $196.36 \mathrm{~mm}$; $p=0.009$ ) increase in the infarction size, in comparison with the wild type (G/G). Genotypes A/C-C/C of the rs761142 polymorphism also had a significant impact $(\rho=0.015)$ on the size of the lesion: we detected an increase in the lesion size by $173.92 \mathrm{~mm}$ in comparison with the AVA genotype (the dominance effect of SNP).

Then, we studied the associations of GCLC polymorphisms with the number of IS survived by the patients (Table 1). The participants were divided into two subgroups: group 1 included patients with a history of one stroke, group 2 comprised patients with a past history of 2 or more strokes. We were able to establish statistically significant associations between 2 SNPs and the number of past ischemic strokes. Carriers of the rs12524494-G/G and rs606548-T/T genotypes were at a higher risk of 2 or more IS than carriers of alternative genotypes (see Table 1).

It is known that the early onset of any multifactorial disease may be associated with genetic factors [14]. So, we attempted to investigate whether GCLC polymorphisms might affect age at ischemic stroke onset. Using linear regression with adjustments for age and sex, we discovered that rs17883901 was significantly associated with age at IS onset. Polymorphism rs17883901, and more specifically, the G/A genotype, was associated with earlier (56.8 \pm 1.65 vs. $60.52 \pm 0.42$ years $)$ onset of the first IS episode ( $p=0.0038$; see Figure).

Using logistic regression, we analyzed association between GCLC polymorphisms and the clinical manifestations of IS, including motor and sensory impairments. Multiple statistically significant associations were established between GCLC polymorphisms and the clinical manifestations of IS. Sensory symptoms were associated with rs636933 (OR $=2.72 ; 95 \% \mathrm{Cl}$ : $1.01-7.33 ; p=0.032)$. The loss of temperature sensation was associated with rs17883901 (OR $=0.27$; 95\% Cl: 0.09-0.86; $p=0.006)$ and $\mathrm{rs} 12524494(\mathrm{OR}=2.25 ; 95 \% \mathrm{Cl}: 1.13-4.46$; $p=0.032)$. The loss of sense of touch was associated with rs12524494 (OR $=2.51 ; 95 \% \mathrm{Cl}: 1.27-4.99 ; p=0.016)$ and rs606548 (OR = 2.36; 95\% Cl: 1.08-5.16; $p=0.04)$. Facial muscle impairment was associated with rs648595 (OR = 0.53; 95\% Cl: $0.34-0.81 ; p=0.0029)$. Gait disturbances were associated with 3 GCLC SNPs: rs648595 (OR = 1.67; 95\% Cl: 1.03-2.71; $p=0.039), \quad r s 761142(\mathrm{OR}=1.50 ; 95 \% \mathrm{Cl}: 1.11-2.01$; $p=0.007)$ and rs636933 (OR $=1.39 ; 95 \% \mathrm{Cl}: 1.03-1.88$; $p=0.03$ ). Muscle weakness was associated with rs761142 $(\mathrm{OR}=1.46 ; 95 \% \mathrm{Cl}: 1.02-2.10 ; p=0.037)$. Diplopia was associated with rs17883901 (OR $=0.12 ; 95 \% \mathrm{Cl}$ : 0.02-0.88; $p=0.0028)$. Strabismus was associated with 2 different SNPs: 


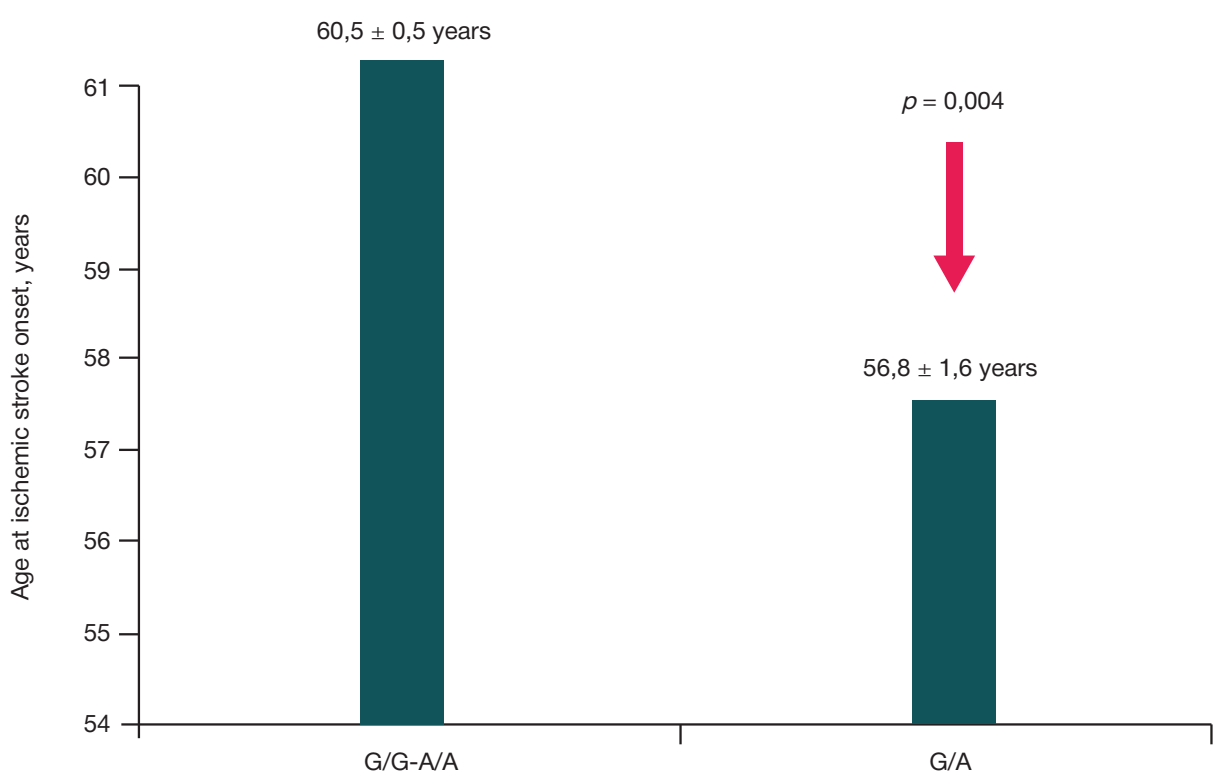

Fig. Associations between the rs17883901 polymorphism of the GCLC gene and age at ischemic stroke onset

rs606548 (OR = 7.68; 95\% Cl: $1.32-44.56 ; p=0.04)$ and rs12524494 (OR = 6.67; 95\% Cl: 1.23-36.24; $p=0.05)$. Dysarthria was associated with rs636933 (OR = 0.69; 95\% Cl: $0.48-0.99 ; p=0.04)$. Vision impairment was associated with rs636933 (OR $=0.61 ; 95 \% \mathrm{Cl}: 0.39-0.94 ; p=0.023$ ).

The analysis of genomic and transcriptomic data on the GCLC gene extracted from the GTEx database allowed us to establish statistically significant cis-eQTLs (expression Quantitative Trait Loci) linked to changes in the transcriptional activity of GCLC. Table 2 illustrates the effects of GCLC polymorphisms on the expression of this gene in different brain regions, arteries, and whole blood. We found that the rs648595-G allele was associated with reduced GCLC expression in basal ganglia $(p=0.00002)$, cerebral cortex $(p=0.000001)$ and blood $(p=1.2 \times 10-70)$. The rs636933-A allele was associated with reduced GCLC in basal ganglia of the brain $(p=0.00005)$ and blood $(p=2.1 \times 10-26)$. The rs761142-C allele was associated with reduced GCLC expression in the blood $(p=5.2 \times 10-52)$, basal ganglia $(p=0.000002)$ and cerebral cortex $(p=0.000004)$. However, rs17883901 was not associated with GCLC expression in any of the analyzed tissue types involved in the pathogenesis of IS.

\section{DISCUSSION}

Our pilot study looked into the effects produced by the polymorphic variants of the gene encoding the key enzyme of glutathione synthesis (the catalytic subunit of glutamate cysteine ligase) on the extent of cerebral damage and the clinical manifestations of IS. The study found that the rs636933 and rs761142 polymorphisms of the GCLC gene are important
DNA markers associated with the size of the cerebral lesion in patients with IS. Besides, the study demonstrates that rs12524494 and rs606548 are significantly associated with an increase in the frequency of IS episodes in the affected patients. The study shows that polymorphism rs17883901 is significantly associated with earlier onset of the first IS episode. The bioinformatic analysis uncovered the functional significance of some polymorphic loci associated with the studied phenotypes. Notably, the alternative alleles of the studied GCLC SNPs have a loss-of-function effect on GCLC expression, as revealed by the analysis of genomic and transcriptomic data from the GTEx database; this suggests a possible association between the expansion of the cerebral lesion and the reduced GCLC expression in the affected brain region. Thus, the obtained data indicate that the studied polymorphic variants of the glutamate cysteine ligase catalytic subunit gene are important DNA markers determining the size of the ischemic stroke lesion and the clinical manifestations of IS. Indeed, the analysis of possible associations between GCLC polymorphisms and the clinical manifestations of ischemic stroke is an important aspect of genetic and epidemiological research and can provide new evidence supporting the pathophysiological implication of the gene in ischemic stroke, thereby allowing researchers to deepen their understanding of molecular mechanisms underlying this pathology [15].

According to the literature, glutathione deficiency in the brain may be indirectly linked to the increased susceptibility of brain tissue to oxidative stress during cerebral artery occlusion. Experiments conducted in astrocyte cultures demonstrated that depletion of the glutathione pool in astrocytes did not affect their viability, at least during the first 24 hours of exposure, but

Table 1. Summary of the associations between GCLC polymorphisms and the number of past ischemic strokes

\begin{tabular}{|c|c|c|c|c|c|}
\hline \multirow{2}{*}{ Gene (SNP ID) } & \multirow{2}{*}{ Genotype, allele } & \multicolumn{2}{|c|}{$n(\%)$} & \multirow{2}{*}{$P^{1}$} & \multirow{2}{*}{ cor $\mathrm{OR}(95 \% \mathrm{Cl})^{2}$} \\
\hline & & Patients with 1 IS & Patients with 2 or more IS & & \\
\hline \multirow{2}{*}{$G C L C A>G(r s 12524494)$} & $\mathrm{A} / \mathrm{A}-\mathrm{A} / \mathrm{G}$ & $518(99.6)$ & $65(97)$ & \multirow{2}{*}{0.05} & 1.00 \\
\hline & $\mathrm{G} / \mathrm{G}$ & $2(0.4)$ & $2(3.0)$ & & $7.78(1.07-56.42)$ \\
\hline \multirow{2}{*}{$G C L C C>T(r s 606548)$} & $\mathrm{C} / \mathrm{C}-\mathrm{C} / \mathrm{T}$ & $470(100.0)$ & $58(96.7)$ & \multirow{2}{*}{0.003} & 1.00 \\
\hline & $T / T$ & $0(0.0)$ & $2(3.3)$ & & $40.2(1.91-847.9)$ \\
\hline
\end{tabular}

Note: ${ }^{1}$ - indicates the significance of the association with the risk of 2 or more IS adjusted for age and sex; ${ }^{2}$ - OR and $95 \%$ Cl for the associations between the studied SNPs and the risk of 2 or more IS adjusted for age and sex. 
Table 2. Effects of GCLC polymorphisms on its expression in the brain, arteries and blood (https://www.gtexportal.org)

\begin{tabular}{|c|c|c|c|c|c|c|c|c|c|c|c|c|}
\hline \multirow{2}{*}{ Ген } & \multirow{2}{*}{ Effect. Allele ${ }^{1}$} & \multirow{2}{*}{ SNP ID } & \multicolumn{2}{|c|}{ Whole blood* } & \multicolumn{2}{|c|}{ Arteries } & \multicolumn{2}{|c|}{ Basal ganglia } & \multicolumn{2}{|c|}{ Cerebellum } & \multicolumn{2}{|c|}{ Cerebral cortex } \\
\hline & & & $p$ & $Z$ & $p$ & beta & $p$ & beta & $p$ & beta & $p$ & beta \\
\hline$G C L C$ & $A>G$ & rs12524494 & $8.5 \times 10^{-18}$ & -8.59 & - & - & - & - & - & - & - & - \\
\hline$G C L C$ & $\mathrm{G}>\mathrm{A}$ & rs17883901 & - & - & - & - & - & - & - & - & - & - \\
\hline GCLC & $C>T$ & rs606548 & $8.8 \times 10^{-16}$ & -8.04 & - & - & - & - & - & - & - & - \\
\hline GCLC & $\mathrm{G}>\mathrm{A}$ & rs636933 & $2.1 \times 10^{-26}$ & -10.63 & - & - & 0.00005 & -0.25 & - & - & - & - \\
\hline$G C L C$ & $T>G$ & rs648595 & $1.2 \times 10^{-70}$ & -17.77 & - & - & 0.00002 & -0.24 & - & - & 0.000001 & -0.21 \\
\hline GCLC & $A>C$ & rs761142 & $5.2 \times 10^{-52}$ & -15.04 & - & - & 0.000002 & -0.27 & - & - & 0.000004 & -0.23 \\
\hline
\end{tabular}

Note: ${ }^{1}$ The allele that was analyzed for the possible effect on GCLC expression is shown in bold. Significant effects of SNPS on GCLC expression ( $\left.p \leq 0.05\right)$ are shown in bold. * $-p$ - the level of statistical significance and the $Z$ - score describing the effects of a given SNP on GCLC expression in the blood (eQTLGen, www.eqtlgen.org).

substantially increased their sensitivity to nitrogen or peroxynitrite [7]. In vivo, the selective depletion of glutathione develops during focal brain ischemia and persists during reperfusion [7]. The time and degree of glutathione depletion are associated with the risk of tissue infarction. A study established that the lesion size significantly decreased after intracerebroventricular infusions of glutathione monoethyl ester, the compound capable of raising mitochondrial glutathione levels [7]. Glutathione monoethyl ester was experimentally proved to have neuroprotective properties in the setting of focal brain ischemia [16]. Thus, changes in glutathione levels may contribute to the severity of tissue damage in patients with ischemic stroke. It is hypothesized that acrolein (a highly toxic $\alpha, \beta$-unsaturated aldehyde) produced in the setting of oxidative cerebral tissue damage is one of the factors contributing to neuronal death linked to the depletion of the reduced intracellular glutathione pool in stroke patients [17].

\section{CONCLUSION}

The polymorphic variants rs636933 and rs761142 of the GCLC gene are important markers determining the size of cerebral infarction in patients with ischemic stroke. Genotypes rs12524494-G/G and rs606548-T/T are associated with an increase in the frequency of IS episodes; genotype rs17883901$\mathrm{G} / \mathrm{A}$ is associated with the early onset of the first IS episode. All SNPs of the GCLC gene studied in this work are significantly associated with the clinical manifestations of IS, including motor and sensory impairments, suggesting the involvement of these SNPs in the pathogenesis of IS. The loss-of-function effects of the studied alleles detected by means of bioinformatic analysis may indicate that the enlargement of the lesion area may be associated with reduced GCLC expression; glutathione deficiency is an unfavorable factor contributing to the severity of brain damage. Our findings provide rationale for clinical trials of the novel IS management and brain damage prevention strategy based on the intravenous injections of reduced glutathione. This may turn out to be an effective protection against neuronal damage provoked by oxidative stress in the setting of ischemia. Besides, the established clinical and genetic associations open up the possibilities for using DNA markers as a tool for assessing the progression of the pathology, predicting its outcomes and offering personalized treatment and prophylaxis to patients based on their ethnogenetics [18].

\section{References}

1. Feigin VL, Lawes CM, Bennett DA, Anderson CS. Stroke epidemiology: a review of population-based studies of incidence, prevalence, and case-fatality in the late $20^{\text {th }}$ century. Lancet Neurol. 2003 Jan; 2 (1): 43-53.

2. Hassan A, Markus HS. Genetics and ischaemic stroke. Brain. 2000 Sep; 123 (Pt 9): 1784-812.

3. Ciancarelli I, Di Massimo C, De Amicis D, Carolei A, Tozzi Ciancarelli MG. Evidence of redox unbalance in post-acute ischemic stroke patients. Curr Neurovasc Res. 2012 May; 9 (2): 85-90.

4. Chehaibi K, Trabelsi I, Mahdouani K, Slimane MN. Correlation of Oxidative Stress Parameters and Inflammatory Markers in Ischemic Stroke Patients. J Stroke Cerebrovasc Dis. 2016 Nov; 25 (11): 2585-93.

5. Juurlink BH, Paterson PG. Review of oxidative stress in brain and spinal cord injury: suggestions for pharmacological and nutritional management strategies. J Spinal Cord Med. 1998 Oct; 21 (4): 309-34.

6. Rodrigo R, Fernández-Gajardo R, Gutiérrez R, Matamala JM, Carrasco R, Miranda-Merchak A, Feuerhake W. Oxidative stress and pathophysiology of ischemic stroke: novel therapeutic opportunities. CNS Neurol Disord Drug Targets. 2013 Aug; 12 (5): 698-714.

7. Sims NR, Nilsson M, Muyderman H. Mitochondrial glutathione: a modulator of brain cell death. J Bioenerg Biomembr. 2004 Aug; 36 (4): 329-33.

8. Bocharova IA. An association study of three polymorphisms in the

glutathione synthase (GSS) gene with the risk of ischemic stroke. Research Results in Biomedicine. 2020; 6 (4): 476-87.

9. Bocharova YuA, Azarova YuE, Klesova EYu, Drozdova EL, Solodilova MA, Polonikov AV. Gen gamma-glutamilciklotransferazy kljuchevogo fermenta katabolizma glutationa i predraspolozhennost' $\mathrm{k}$ ishemicheskomu insul'tu: analiz associacij $\mathrm{s}$ bolezn'ju i funkcional'noe annotirovanie DNK-polimorfizmov. Medicinskaja genetika. 2020; 19 (10): 32-39. Russian.

10. Bioinformaticheskij instrument GenePipe. Available from: https:// snpinfo.niehs.nih.gov/snpinfo/selegene.html.

11. Bioinformaticheskaja programma FuncPred. Available from: https://snpinfo.niehs.nih.gov/snpinfo/snpfunc.html.

12. Bioinformaticheskij instrument GTEx portal. Available from: https://gtexportal.org.

13. Bioinformaticheskij instrument eQTLGen. Available from: www. eqtlgen.org.

14. Ruse CE, Parker SG. Molecular genetics and age-related disease. Age Ageing. 2001 Nov; 30 (6): 449-54.

15. Janssens AC, van Duijn CM. Genome-based prediction of common diseases: advances and prospects. Hum Mol Genet. 2008 Oct 15; 17 (R2): R166-73.

16. Anderson MF, Nilsson M, Eriksson PS, Sims NR. Glutathione monoethyl ester provides neuroprotection in a rat model of stroke. Neurosci Lett. 2004 Jan 9; 354 (2): 163-5. 
17. Liu JH, Wang TW, Lin YY, Ho WC, Tsai HC, Chen SP, et al. Acrolein is involved in ischemic stroke-induced neurotoxicity through spermidine/spermine-N1-acetyltransferase activation. Exp Neurol. 2020 Jan; 323: 113066.

\section{Литература}

1. Feigin VL, Lawes CM, Bennett DA, Anderson CS. Stroke epidemiology: a review of population-based studies of incidence, prevalence, and case-fatality in the late $20^{\text {th }}$ century. Lancet Neurol. 2003 Jan; 2 (1): 43-53.

2. Hassan A, Markus HS. Genetics and ischaemic stroke. Brain. 2000 Sep; 123 (Pt 9): 1784-812.

3. Ciancarelli I, Di Massimo C, De Amicis D, Carolei A, Tozzi Ciancarelli MG. Evidence of redox unbalance in post-acute ischemic stroke patients. Curr Neurovasc Res. 2012 May; 9 (2): 85-90.

4. Chehaibi K, Trabelsi I, Mahdouani K, Slimane MN. Correlation of Oxidative Stress Parameters and Inflammatory Markers in Ischemic Stroke Patients. J Stroke Cerebrovasc Dis. 2016 Nov; 25 (11): 2585-93.

5. Juurlink $\mathrm{BH}$, Paterson PG. Review of oxidative stress in brain and spinal cord injury: suggestions for pharmacological and nutritional management strategies. J Spinal Cord Med. 1998 Oct; 21 (4): 309-34.

6. Rodrigo R, Fernández-Gajardo R, Gutiérrez R, Matamala JM, Carrasco R, Miranda-Merchak A, Feuerhake W. Oxidative stress and pathophysiology of ischemic stroke: novel therapeutic opportunities. CNS Neurol Disord Drug Targets. 2013 Aug; 12 (5): 698-714.

7. Sims NR, Nilsson M, Muyderman H. Mitochondrial glutathione: a modulator of brain cell death. J Bioenerg Biomembr. 2004 Aug; 36 (4): 329-33.

8. Bocharova IA. An association study of three polymorphisms in the glutathione synthase (GSS) gene with the risk of ischemic stroke. Research Results in Biomedicine. 2020; 6 (4): 476-87.

9. Бочарова Ю. А., Азарова Ю. Э., Клёсова Е. Ю., Дроздова Е. Л., Солодилова М. А., Полоников А. В. Ген гамма-
18. Mirzaev K, Abdullaev S, Akmalova K, Sozaeva J, Grishina E, Shuev $G$, et al. Interethnic differences in the prevalence of main cardiovascular pharmacogenetic biomarkers. Pharmacogenomics. 2020; 21 (10): 677-94.

глутамилциклотрансферазы - ключевого фермента катаболизма глутатиона и предрасположенность к ишемическому инсульту: анализ ассоциаций с болезнью и функциональное аннотирование ДНК-полиморфизмов. Медицинская генетика. 2020; 19 (10): 32-39.

10. Биоинформатический инструмент GenePipe. Доступно по ссылке: https://snpinfo.niehs.nih.gov/snpinfo/selegene.html.

11. Биоинформатическая программа FuncPred. Доступно по ссылке: https://snpinfo.niehs.nih.gov/snpinfo/snpfunc.html.

12. Биоинформатический инструмент GTEx portal. Доступно по ссылке: https://gtexportal.org.

13. Биоинформатический инструмент eQTLGen. Доступно по ссылке: www.eqtlgen.org.

14. Ruse CE, Parker SG. Molecular genetics and age-related disease. Age Ageing. 2001 Nov; 30 (6): 449-54.

15. Janssens AC, van Duijn CM. Genome-based prediction of common diseases: advances and prospects. Hum Mol Genet. 2008 Oct 15; 17 (R2): R166-73.

16. Anderson MF, Nilsson M, Eriksson PS, Sims NR. Glutathione monoethyl ester provides neuroprotection in a rat model of stroke. Neurosci Lett. 2004 Jan 9; 354 (2): 163-5.

17. Liu JH, Wang TW, Lin YY, Ho WC, Tsai HC, Chen SP, et al. Acrolein is involved in ischemic stroke-induced neurotoxicity through spermidine/spermine-N1-acetyltransferase activation. Exp Neurol. 2020 Jan; 323: 113066.

18. Mirzaev K, Abdullaev S, Akmalova K, Sozaeva J, Grishina E, Shuev $G$, et al. Interethnic differences in the prevalence of main cardiovascular pharmacogenetic biomarkers. Pharmacogenomics. 2020; 21 (10): 677-94. 